Available online at GSC Online Press Directory

GSC Biological and Pharmaceutical Sciences

e-ISSN: 2581-3250, CODEN (USA): GBPSC2

(RESEARCH ARTICLE)

\title{
Study the effect of some traditional plant extracts to Escherichia coli on Jeddah province
}

Almutiri Anoud Abdullah, Jastaniyah Bashayer Atif, Alharbi Basma Turki, Alzahrani Bothynah Abdulaziz, Alharbi Esraa Hamad, Asiri Fatima Essa, Almabary Fatemah Jamal, Alharbi Hadeel Sultan, Ahmed Hibah Abdulmannan, Sabbagh Hind Tawfeek, Alabsi Khadijah Yahya, Qasem Lojain Khalil, Fadhel Lujain Ibrahim, Alqhtani Najwa Ayid, Aljehani Rawan Awad, Alhusseini Renad Abdulrahman, Lamfon Salmah Ahmed, Alsamadani Shurooq Ahmed, Yousef Wed Mohammed, Alghamdi Wed Saeed, Hakami Nouf Mohammed and Sharawi Somia Essa *

Department of Biological Sciences, Faculty of Science, King Abdulaziz University, Saudi Arabia, Jeddah Province.

Publication history: Received on 14 November 2019; revised on 28 November 2019; accepted on 01 December 2019

Article DOI: https://doi.org/10.30574/gscbps.2019.9.3.0213

\begin{abstract}
Plants are a source of chemical compounds such as alkaloids, steroids, essential and fixed oils, which can be used against many diseases. Here, we evaluated the aqueous and solvent extract of four plants (Syzygium aromaticum, Elettaria cardamomum, Nigella sativa, Capsicum annuum), and assessed their antimicrobial activity against Escherichia coli using will diffusion method after $24 \mathrm{~h}$. The oil crude extract of $S$. aromaticum showed the highest antimicrobial activity, while the oil crude extract of $C$. annuum showed the lowest activity. Our study revealed that the utilization of aqueous and solvent extract of some traditional plants against $E$. coli would be an effective way in the management of some environmental bacterial diseases.
\end{abstract}

Keywords: Hydro distillation; Soxhlet; Solvent extract; E. coli; Jeddah

\section{Introduction}

For a long time, human used plant resources in many applications, such as antibiotics, perfumes, insecticides, food and cure many diseases $[1,2]$. These plants contain many active compounds which called sometimes crude extract, like essential oils, phenols, and flavonoids which found in many parts in the plant such as leaves, flowers, bark, seeds, fruits, and roots [2]. This crude extract can be separated from the plant using extraction methods, which are one of the easier ways [3]. The essential oils are natural components, made in the plant within the procedure of secondary metabolism [4].

A wide range of essential oils has been discovered from a long time which can cure a diverse range of diseases and pathogens [4]. This disease such as cardiovascular, diabetes, Alzheimer's, cancer [5], besides, the antimicrobial impacts were studied by many researchers [6].

At present, the side effect of bacteria still the big problem of human death, until this moment. In this regard, plant essential oils especially the traditional one, is the most effective as antibacterial agents which can prevent the growth of the bacteria or ruin their cells [4]. Traditional plants have been proved to be a novel source in the search of antimicrobial compounds [7]. Several types of essential oils have been studied to control a wide range of bacteria like clove oil. Clove bud oil showed a strong antibacterial effect against Salmonella typhi, Staphylococcus aureus, and Pseudomonas aeruginosa [8]. Likewise, carvacrol, eugenol, and thymol essential oils were inhibited E. coli [9]. [10]

\footnotetext{
${ }^{*}$ Corresponding author

E-mail address: sesharawi@kau.edu.sa
} 
studied the antimicrobial activity of water extract of clove and black pepper on E. coli. In another study, Salvia spp. and Thuja spp. essential oils were strongly antimicrobial against E. coli.

In this study four traditional plants (S. aromaticum, E. cardamomum, N. sativa and C. annuum), were purchased from local markets from Jeddah and extracted using aqueous and solvent extraction. All extractions effects were studied against E.coli using will diffusion method.

\section{Material and methods}

\subsection{Plant material and extract preparation}

Plants In the current study were purchased from local markets. The laboratory bioassay was conducted at the Biological Labs, belonging to the Department of Biological Sciences, Faculty of Sciences, King Abdul-Aziz University, Jeddah, Saudi Arabia.

\subsection{Hydro distillation}

Hydro distillation method was done according to [11] with some modifications. 50 gram of $S$. aromaticum and $E$. cardamomum were extracted using Clevenger apparatus $250 \mathrm{ml}$ of water. The process was running for 6 hours.

\subsection{Soxhlation}

Soxhlation method was done according to [12] with some modifications. $25 \mathrm{~g}$ of $N$. sativa and C. annuum were extracted in a soxhlet apparatus using ethanol as a solvent $(150 \mathrm{ml})$ for 6 hours. A constant temperature of about $55{ }^{\circ} \mathrm{C}$ was maintained throughout the extraction process. After extraction, the solvent was removed using a rotary evaporator (EYELA, N-1110).

\subsection{Identification of bacterial strains}

E. coli pure isolates used in this study were provided from the Microbiology Laboratory of King Abdul Aziz University, Faculty of Sciences. All samples were sub-cultured in nutrient broth, and the inoculated broth tubes were incubated at $37^{\circ} \mathrm{C}$, for 24 hours. Petri dishes were then prepared using nutrient agar, to apply will diffusion method.

\subsection{Will diffusion Method}

The antibacterial screening of the plant extracts against $E$. coli bacteria was carried out by determining the zone of inhibition using will diffusion method after $24 \mathrm{~h}$. [13].

\subsection{Statistical analysis}

Agar well diffusion assay was performed in triplicate under strict aseptic conditions to ensure consistency of all findings.

\section{Results}

\subsection{Plant extraction}

In this study, S. aromaticum and E. cardamomum were extracted using hydrodistillation and N. sativa and C. annuum were extracted in a soxhlet. Oil was extracted only from S. aromaticum and N. sativa, oil and water were extracted from E. cardamomum and C. annuum as in (Figure 1). 


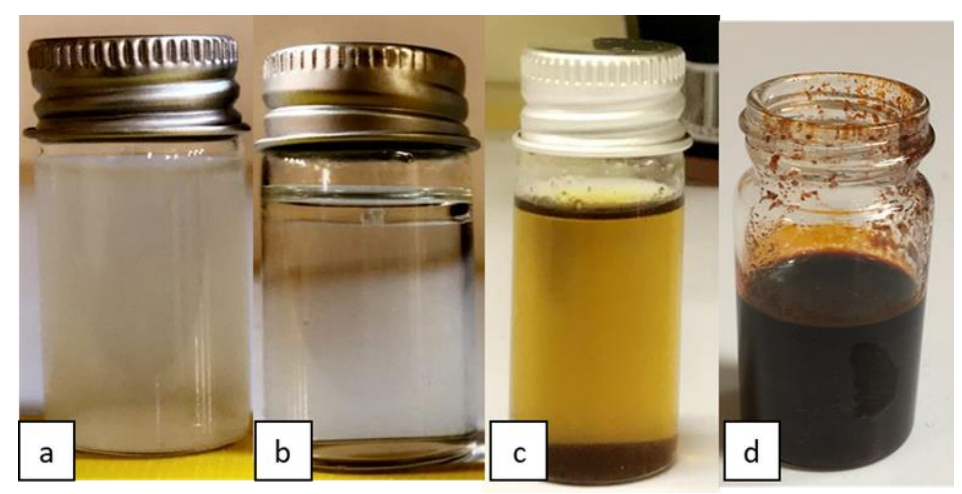

Figure 1 plant extract a- water and oil of S. aromaticum, b-water and oil of E. cardamomum, c-oil of $N$. sativa, d-oil of $C$. annuum

\subsection{Effect of plants extracts on E. coli}

The antibacterial screening of the plant extracts against E. coli was carried out by determining the zone of inhibition using will diffusion method after $24 \mathrm{~h}$. We have observed as in (Table 1) that, the water extract from $S$. aromaticum, E. cardamomum and the oil extracted from N. sativa was not inhibited to E. coli and did not show antibacterial screening.

Table 1 Antibacterial activity of aqueous and solvent extracts of tested plants

\begin{tabular}{|c|c|c|}
\hline \multirow[t]{2}{*}{ Sample } & & $\begin{array}{l}\text { Diameter of zone of } \\
\text { inhibition }(\mathrm{mm}) \text { after } 24 \mathrm{~h} . *\end{array}$ \\
\hline & & E. coli \\
\hline \multirow{2}{*}{$\begin{array}{l}\text { Water } \\
\text { extract }\end{array}$} & S. aromaticum & $\mathrm{NI}$ \\
\hline & E. cardamomum & $\mathrm{NI}$ \\
\hline \multirow[t]{4}{*}{ Oil extract } & S. aromaticum & 10 \\
\hline & E. cardamomum & NI \\
\hline & $N$. sativa & $\mathrm{NI}$ \\
\hline & C. апnuum & 5 \\
\hline Control & & $\mathrm{NI}$ \\
\hline
\end{tabular}

Values of the observed diameter zone of inhibition (mm) including the diameter of well after 24 h incubation against E.coli when subjected to different extracts in agar well diffusion assay. In each well, the sample size was $100 \mu \mathrm{L} . ;{ }^{* *} \mathrm{NI}$ : no inhibition zone was observed; ${ }^{* *}$ Sterilized water was used as a control

Extracted oil from S. aromaticum and C. annuum showed favorable result against tested bacterial after 24 h., E.coli showed the maximum susceptibility towards $S$. aromaticum oil with $10 \mathrm{~mm}$ zone of inhibition, and the antibacterial activity of $C$. annuum oil against $E$. coli showed a zone of inhibition $5 \mathrm{~mm}$.

\section{Discussion}

Antibacterial activity of different extracts prepared from tested plants was expressed in terms of zone of inhibitions after $24 \mathrm{~h}$. We have observed that only oil extract of $S$. aromaticum has the strongest effect as an antimicrobial against $E$. coli. This result has been studied by many authors $[14,15]$. Also, we investigated that water and oil extract of $E$. cardamomum did not show any inhibition zone after $24 \mathrm{~h}$., the same result was studied by [7], who indicated that antibacterial activity of E. cardamomum is dependent on the type of extract and the organism evaluated, and he found that ethanol extract was comparatively higher activity than other organic and aqueous extracts. Our results found that $N$. sativa oil did not prevent the growth of $E$. coli after $24 \mathrm{~h}$. Unlike a several number of authors who mentioned that the antimicrobial activity of $N$. sativa was observed. Also, [16] had proven that both the crude alkaloid extract and the water extract of the $N$. sativa were effective against some tested microorganisms like staphylococcus. Another finding in our study is that the antimicrobial activities of $C$. annuum showed good activities against E. coli. These findings tend to support the findings by [17], which indicating that all types of capsicum are a useful as antibacterial agent. 


\section{Conclusion}

Most of the traditional plants possess antimicrobial activity due to presence of the phytochemicals. Therefore, it has been suggested that the different extracts from traditional plant in Saudi Arabia might be used as alternative antimicrobial natural substances and play a great role in the discovery of new drugs.

\section{Compliance with ethical standards}

\section{Acknowledgments}

The authors express their sincere gratitude to Dr. Mona Alharbi the supervisor of the Biology Department and Dr. Sameera Alghamdi the supervisor of the Botany Section for their nice cooperation and support for field training students. Also, special thanks to the Biological Labs in girls' branch, belonging to the Department of Biological Sciences, Faculty of Sciences, King Abdul-Aziz University, Jeddah, Saudi Arabia.

\section{Disclosure of conflict of interest}

It has declared that the authors of the study have no conflict of interest among them.

\section{References}

[1] Zamin I, Shah JA, Khan I, Majid A, Rehman MM, Malik Z, Hyder H, Bibi J and Naz B. (2015). In-Vitro efficacy of crude extract of Zizipus Jujuba against selected bacterial strains. Int. J. Sci. Res. Pub, 4 (2), 1-5.

[2] Gupta N, Naraniwal M and Kothari V. (2012). Modern Extraction Methods for Preparation of Bioactive Plant Extracts. International Journal of Applied and Natural Sciences, 1 (1), 8-26.

[3] Jadhav D, Rekha BN, Gogate PR and Rathod VK. (2009). Extraction of vanillin from vanilla pods: A comparison study of conventional Soxhlet and ultrasound assisted extraction. J. Food Eng, 93 (4), 421-426.

[4] Swamy MK, Akhtar MS and Sinniah UR. (2016). Antimicrobial Properties of Plant Essential Oils against Human Pathogens and Their Mode of Action: An Updated Review. Evidence-based complementary and alternative medicine, eCAM.

[5] Ali B, Al-Wabel NA, Shams S, Ahamad A, Khan SA and Anwar F. (2015). Essential oils used in aromatherapy: a systemic review. Asian Pacific Journal of Tropical Biomedicine, 5 (8), 601-611.

[6] Akhtar MS, Degaga B and Azam T. (2014). Antimicrobial activity of essential oils extracted from medicinal plants against the pathogenic microorganisms: a review. Biological Sciences and Pharmaceutical Research, 2 (1), 1-7.

[7] Kaushik P, Goyal P, Chauhan A and Chauhan G. (2010). In Vitro Evaluation of Antibacterial Potential of Dry Fruit Extracts of Elettaria cardamomum Maton (Chhoti Elaichi). Iran J Pharm Res, 9 (3), 287-92.

[8] Conner. (1993). Naturally occurring compounds. In: Davidison PM, Branen AL, editors. Antimicrobials in Foods. New York, NY, USA: Marcel Dekker.

[9] Kim J, Marshall MR and Wei CI. (1995). Antibacterial activity of some essential oil components against five foodborne pathogens. Journal of Agricultural and Food Chemistry, 43 (11), 2839-2845.

[10] Arora DS and Kaur J. (1999). Antimicrobial activity of spices. International Journal of Antimicrobial Agents, 12 (3), 257-62.

[11] Afrudin I, Maimulyanti A and Prihadi AR. (2015). Effect of crushing of clove bud (Syzygium aromaticum) and distillation rate on main constituents of the essential oil. American Journal of Essential Oils and Natural Products, $2(3), 12-15$.

[12] Sarwa KK, Mazumder B and Rudrapal M. (2016). Effect of extraction methods and longterm storage on capsaicinoids conten of Bhut Jolokia fruits. Indian Journal of Natural Products and Resources, 8 (1), 69-77.

[13] Sahoo S, Kar DM, Mohapatra S, Rout SP and Dash SK. (2006). Antibacterial activity of Hybanthus enneaspermus against selected UTI pathogens. Indian Journal of Pharmaceutical Sciences, 68 (5), 653-655.

[14] Huang Y, Ho SH, Lee HC and Yap YL. (2002). Insecticidal properties of eugenol, isoeugenol and methyleugenol and their effects on nutrition of Sitophilus zeamais Motsch. J. Stored Prod. Research, 38 (5), 403-412. 
[15] Matan N, Rimkeeree H, Mawson AJ, Chompreeda P, Haruthaithanasan V and Parker M. (2006). Antimicrobial activity of cinnamon and clove oils under modified atmosphere conditions. J. Food Microbiol, 107 (2), 180-5.

[16] Morsi NM. (2000). Antimicrobial effect of crude extracts of NS and multiple antibiotics-resistant bacteri. Acta Microbiol, 49 (1), 63-74.

[17] Soetarno S, Sukrasno EY and Sylvia S. (1997). Antimicrobial Activities of the Ethanol Extracts of Capsicum Fruits with Different Levels of Pungency. Jurnal Matematika dan Sains, 2 (2), 57-63.

\section{How to cite this article}

Almutiri AA, Jastaniyah BA, Alharbi BT, Alzahrani BA, Alharbi EH, Asiri FE, Almabary FJ, Alharbi HS, Ahmed HA, Sabbagh HT, Alabsi KY, Qasem LK, Fadhel LI, Alqhtani NA, Aljehani RA, Alhusseini RA, Lamfon SA, Alsamadani SA, Yousef WM, Alghamdi WS, Hakami NM and Sharawi SE. (2019). Study the effect of some traditional plant extracts to Escherichia coli on Jeddah province. GSC Biological and Pharmaceutical Sciences, 9(3), 08-12. 